\title{
ステンレス鋼一構造用鋼ハイブリッド 圧縮補剛板の耐荷力評価
}

\author{
松下 裕明 1 - 矢吹 哲哉 2 - 有住 康則 3 -下里 哲弘 4 \\ 1正会員 日立造船株式会社 機械インフラ本部（†559-8599 大阪市住之江区南港北1-7-89） \\ E-mail: matsushita@hitachizosen.co.jp \\ 2フェロー 琉球大学名誉教授（†903-0213 沖縄県中頭郡西原町千原1） \\ E-mail: yabuki@tec.u-ryukyu.ac.jp \\ 3正会員 琉球大学教授 環境建設工学科（下903-0213 沖縄県中頭郡西原町千原1） \\ E-mail: arizumi@tec.u-ryukyu.ac.jp \\ 4正会員 琉球大学准教授 環境建設工学科（干903-0213 沖縄県中頭郡西原町千原1） \\ E-mail: simozato@tec.u-ryukyu.ac.jp
}

\begin{abstract}
著者らは鋼橋の耐久性向上の一方策として, 耐食性の確保と低コスト化の観点から箱内補剛材を従来の 構造用鋼とし，その外膜材にステンレス鋼を用いたステンレス橋梁を提案している. 本研究では, ステン レス橋梁に用いられるハイブリッド補剛板を対象にパラメトリックな解析的検討を行うことによりその圧 縮而荷力特性を明らかにし, 従来の構造用鋼と同等の評価が可能であることを定量的に示した. 耐荷力評 価に際して，パラメトリック解析で設定した解析モデルの適用性は実験結果と比較することにより確認さ れている.
\end{abstract}

Key Words : stainless steel, hybrid stiffened plate, ultimate compressive strength, nonlinear finite element analysis, tri-linear stress strain relation

\section{1. まえがき}

近年，社会資本整備に関する維持管理コストの増加と ともに土木構造物に対する而久性向上や環境負荷低減へ の要求がますます高まってきている，このような中，著 者らは鋼橋の長期防食性確保と初期コス卜低減の観点か ら，図-1に示すように，外気接触面となる外膜材をステ ンレス鋼とし，腐食環境が比較的㛜しくなく，かつ維持 管理のための近接が容易な箱内補剛材を従来の構造用鋼 としたステンレス橋梁を提案1)のしている. しかし，ス テンレス鋼の応力ーひずみ関係は一般に鋼橋に用いられ る構造用圧延鋼材 ${ }^{7}$ （以下，構造用鋼と呼ぶ）に比べ, 降伏棚を持たず低い応力レベルから非線形性が現われる 一方でひずみ硬化が大きい点が異なる．よって，ステン レス橋梁の実用化のためには，ステンレス鋼特有の応力 一ひずみ関係を考慮した部材の強度特性を明らかにする 必要がある。

鋼橋は比較的薄肉の鋼板を溶接集成した部材から構成 されるため, 従来から構造用鋼を対象として無補岡川圧縮 板や圧縮補剛板の而荷力特性に関する実験的 - 解析的研
究が精力的になされてきた ${ }^{8), 99}$. ステンレス鋼を用いた 部材の耐荷力特性に関する研究としては建築用の骨組部 材に用いる $\mathrm{H}$ 形鋼 $^{10)}$ や鋼管 $^{11)}$ に関するもの，およびこれ らの研究に基づく設計指針 ${ }^{12}$ などがある．橋梁用のI形や 箱形断面部材を構成する鋼板の諸元を有するステンレス

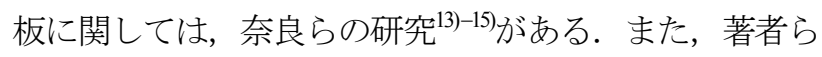
はこれまでにステンレス鋼を用いた補岡板 ${ }^{1)}$, 腹板 ${ }^{4)}$,5)お よび自由突出板のを対象に，実験および解析的にその耐

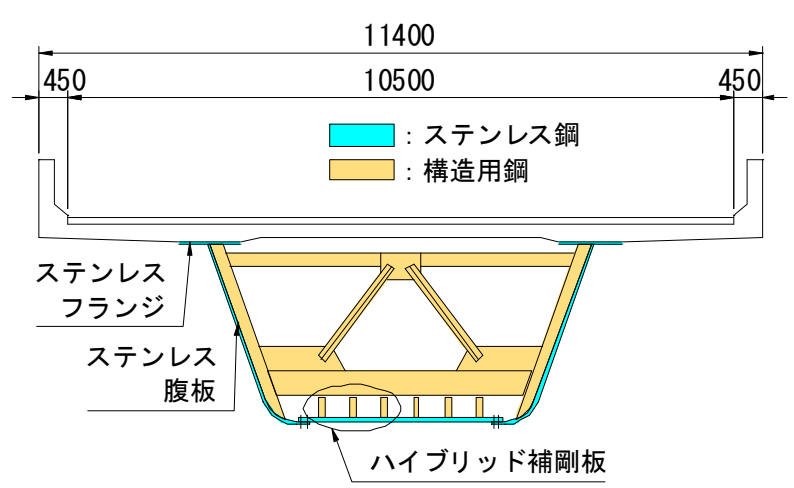

図-1 ステンレス橋梁の例 
荷力特性を研究している. しかし，ステンレス橋梁の開 発の一環として，構造用鋼で補剛された複合ステンレス 補剛板（以下，ハイブリッド補剛板と呼ぶ）に着目した 研究は極めて少ない1). そこで本研究では，ハイブリッ ド補剛板を対象とし，パラメトリックな解析的検討によ りその圧縮而渮力特性を明らかにすることを目的とする。

本論文では，まず初めに，別途実施したハイブリッド 補剛板の耐荷力実験供試体 ${ }^{1}$ を対象に弾塑性有限変位解 析を行い，パラメトリック解析に用いる初期不整のモデ ル化，および著者らが提案するトリリニア型の材料構成 式の適用性について検討した。次に，検討結果を反映し た解析モデルを用いてハイブリッド補剛板の而荷力に影 響を及ぼすと考えられる因子を変化させてパラメトリッ ク解析を行い，その耐荷力特性を明らかにした。

\section{2. 弾塑性有限変位解析モデル}

\section{(1) 解析手法}

採用解析モデルの適用性を確認するために実駼結果 ${ }^{1)}$ との比較検討を行った，比較解析対象は図-2に示寸よう に一本の縦補剛材を有するハイブリッド補剛板供試体と した. 供試体諸元を表-1に示す. 板パネルにはオーステ ナイト系ステンレス鋼SUS304N2A（JIS G 4321 : 建築構 造用ステンレス鋼）を，縦補剛材には構造用鋼SM490Y を使用し，表-1に示すように板パネルの厚さが異なる2 種類の供試体を対象とした．なお，表中の板パネルの幅 厚比パラメータ $R$, および補剛材剛比 $\gamma$ は式(1)および 式(2)を用いて算出した.

$$
\begin{gathered}
R=\frac{b}{t} \sqrt{\frac{\sigma_{0.1}}{E_{0}} \cdot \frac{12\left(1-v^{2}\right)}{4 \cdot \pi^{2}}} \\
\gamma=\left(\frac{t_{r} h_{r}^{3}}{3}\right) /\left(\frac{n b t^{3}}{11}\right)
\end{gathered}
$$

ここに, $\sigma_{0.1}$ はSUS304N2Aの0.1\%耐力, $E_{0}$ は初期弾性係 数, $v$ はポアソン比, $n$ は縦補剛材で区切られるパネル
数であり, その他の值は表-1に示寸通りである. また, 表中の $\gamma_{r e q}$ は道路橋示方書》で規定された縦補剛材の必 要剛比を示寸.

図-3に示すように解析対象は実験供試体と同じ寸法形 状とし，境界条件を実駼供試体に合わせて載荷辺を固定 支持，非載荷辺を単純支持とした．解析ではハイブリッ ド補剛板，ステンレス腹板，およびステンレス鋼圧縮フ ランジの耐荷力特性の検討で適用性を確認したアイソパ ラメトリックシェル要素を用いた弾塑性有限変位理論に 基づく数值解析法を用いた プログラムMSC.Marcを用い, 要素は8節点厚肉曲面シ エル要素（要素番号22）を用いた，要素分割は図に示す ように板パネルの長さおよび幅をそれぞれ16および12分 割, 縦補剛材の長さおよび高さをそれぞれ16および3分 割とした．載荷は縦補剛材を含む載荷辺に一様な強制変

一様 軸 圧 縮 荷 重
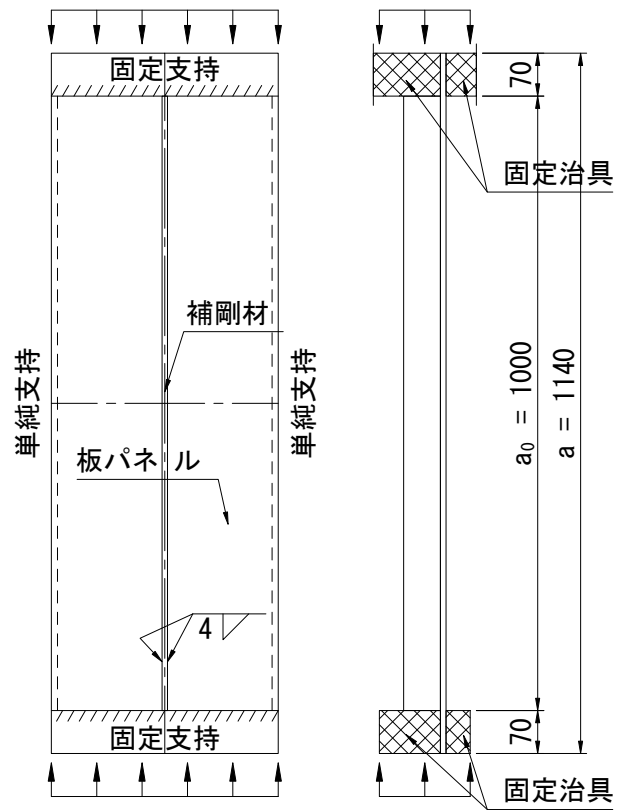

一様

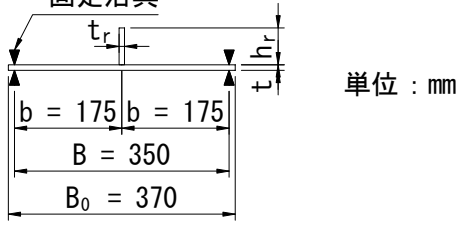

図-2 実験供試体

\begin{tabular}{|c|c|c|c|c|c|c|c|c|c|c|c|c|c|}
\hline \multirow{3}{*}{$\begin{array}{c}\text { 供試体 } \\
\text { 種別 }\end{array}$} & \multicolumn{8}{|c|}{ 板パネル } & \multicolumn{5}{|c|}{ 補剛材 } \\
\hline & \multicolumn{3}{|c|}{ 板幅(mm) } & \multirow{2}{*}{$\begin{array}{c}\text { 板厚 } \\
\mathrm{t} \\
\mathrm{mm}\end{array}$} & \multirow{2}{*}{$\begin{array}{l}\text { パネル } \\
\text { 数 } n\end{array}$} & \multirow{2}{*}{$\begin{array}{c}\text { 幅厚比 } \\
b / t\end{array}$} & \multirow{2}{*}{$\begin{array}{c}\text { 幅厚比 } \\
\text { パラ } \\
\text { メータ } \\
\mathrm{R}\end{array}$} & \multirow[b]{2}{*}{ 使用鋼材 } & \multirow{2}{*}{$\begin{array}{c}\text { 高さ } \\
\mathrm{h}_{\mathrm{r}} \\
\mathrm{mm}\end{array}$} & \multirow{2}{*}{$\begin{array}{c}\text { 板厚 } \\
t_{r} \\
m m\end{array}$} & \multirow{2}{*}{$\begin{array}{c}\text { 幅厚比 } \\
h_{r} / t_{r}\end{array}$} & \multirow{2}{*}{$\begin{array}{c}\text { 必要剛比 } \\
\gamma / \gamma_{\text {req }}\end{array}$} & \multirow[b]{2}{*}{ 使用鋼材 } \\
\hline & $\begin{array}{c}\text { 全幅 } \\
\mathrm{B}_{0} \\
\end{array}$ & $\begin{array}{c}\text { 幅 } \\
\text { B }\end{array}$ & $\begin{array}{l}\text { パネル } \\
\text { 幅 b } \\
\end{array}$ & & & & & & & & & & \\
\hline A & \multirow{2}{*}{370} & \multirow{2}{*}{350} & \multirow{2}{*}{175} & 6.1 & \multirow{2}{*}{2} & 29 & 0.70 & \multirow{2}{*}{ SUS304N2A } & 60 & 8.6 & 7.0 & 1.6 & \multirow{2}{*}{ SM490Y } \\
\hline$B$ & & & & 9.2 & & 19 & 0.47 & & 70 & 8.6 & 8.1 & 1.1 & \\
\hline
\end{tabular}

表-1 ハイブリッド補剛板実験供試体の諸元

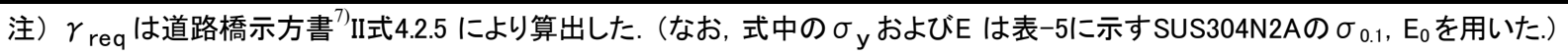


位を与えることにより一様軸圧縮力を導入する方法を用 いた.

\section{(2) 材料構成式}

\section{a) 降伏点（0.1\%耐力）}

鋼橋の設計では一般的に基準強度に降伏点を用い，座 屈挙動による強度低下は基準強度からの低減率で規定さ れるクことから，降伏点の設定は重要となる.

図-4にJIS規格材料試験片によるSUS304N2Aの材料試験 結果の一例" を示す．図に示すようにその応力ーひずみ 関係は降伏棚を持たない，いわゆるラウンド八ウス型と なる.このような降伏棚を持たない鋼材の降伏点は一般 にオフセット法 ${ }^{16} を$ 用いた $0.2 \%$ 耐力が用いられる ${ }^{17)}$. し かし，本研究で取り扱うSUS304N2Aは，JS規格化され るにあたり各鋼材メーカーによる鋼材の試験值を総合的 に判断し, 設計基準強度として用いられる降伏点として $0.1 \%$ 耐力が採用されている ${ }^{18)}$. よって, 本研究では SUS304N2Aの降伏点として0.1\%而扵をを採用した.

\section{b) 初期弾性係数と比例限度}

ステンレス鋼の初期弾性係数は適用する規準毎に異な り，例えばSUS304に代表されるオーステナイト系の熱 間圧延ステンレス鋼材はBS/ENにおいて200,000 N/ $\mathrm{mm}^{2}$, ASCEにおいて193,100 N/mm が採用されている ${ }^{19}$. また, 国内でSUS304N2AのJIS規格化にあたり規定されたステ ンレス建築構造の設計基準 ${ }^{12)}$ では193,000 $/ \mathrm{mm}^{2}$ が採用さ れている.一方，図-5は著者らが行った材料試験結果の 一例であるが，初期の段階から緩やかな接線岡性の低下 が見られ，例えば，初期弾性係数を図中の $200,000 \mathrm{~N} / \mathrm{mm}^{2}$, 193,000 N/mm²のいずれかに決定することは困難であるこ とが分かる、よって，本研究では，SUS304N2Aの国内で の建築構造物の設計基準に用いられていること，および 著者らが別途行った材料試験引において接線剛性の最大 值が200,000 N/ $\mathrm{mm}^{2}$ 以下となる試験体があったことから， 初期弾性係数は193,000 N/mm² とした。

また，比例限度は図に示すように割線弾性係数が 193,000 N/mm 点の応力度を採用した.

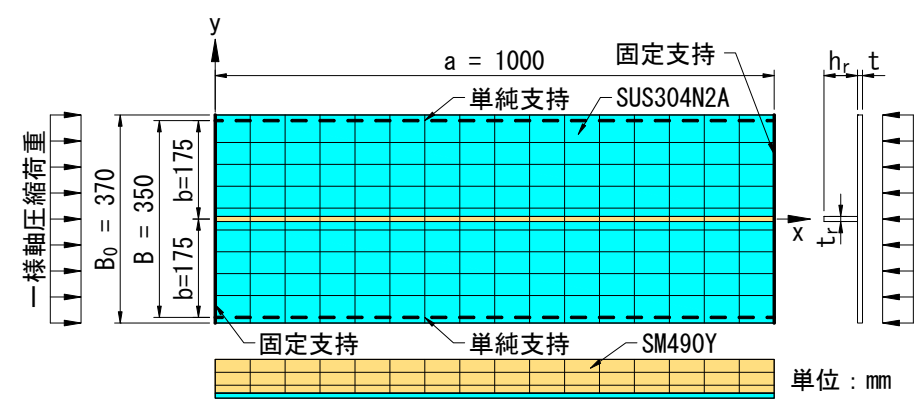

図-3 解析モデル

\section{c) 応カーひずみ関係}

SUS304N2Aのようなラウンド八ウス型の応力ーひずみ 関係を有する金属材料の構成式としては，式(3)に示す Ramberg-Osgood曲線20)が一般的である.

$$
\varepsilon=\frac{\sigma}{E_{0}}+0.002\left(\frac{\sigma}{\sigma_{0.2}}\right)^{n}
$$

ここに, $\sigma_{0.2}$ は $0.2 \%$ 耐力での応力度, $n$ は硬化パラメー タである. 硬化パラメータ $n$ は材料試験による代表的な 1点，例えば $0.01 \%$ 耐力の通過を条件 ${ }^{21}$ とすることで決定 できる．しかし，本式は $0.2 \%$ 耐力を超える領域での精度 の低下が指摘されており，0.2\%耐力を境界として 2 種類 のRamberg-Osgood曲線が滑らかに接続するように拡張 したNethercotらの構成式 ${ }^{22}$ や，さらに原点から比例限度 までを線形弾性に修正した奈良らの構成式 ${ }^{15)}$ などが提案 されている．また，国内の建築分野においては，式(4) に示すSUS304を対象とした中務・中村の式 ${ }^{23}$ が提案され ている.

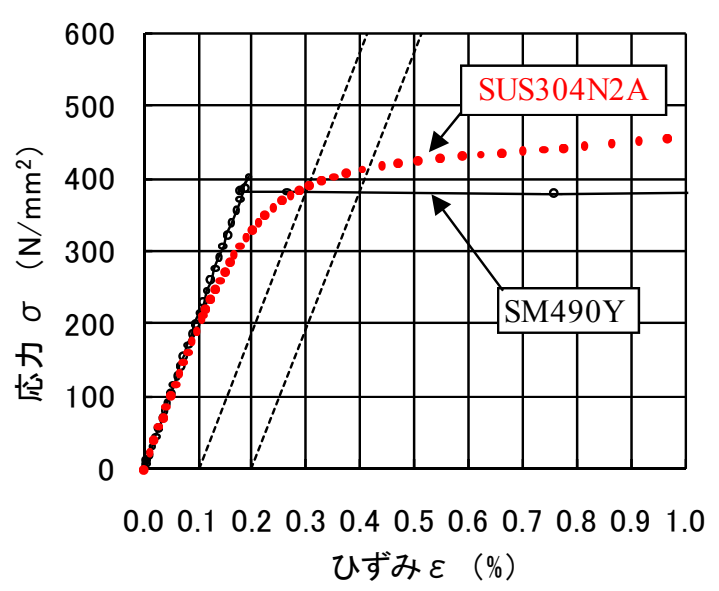

図-4 材料試験結果（応力ーひずみ関係）の例

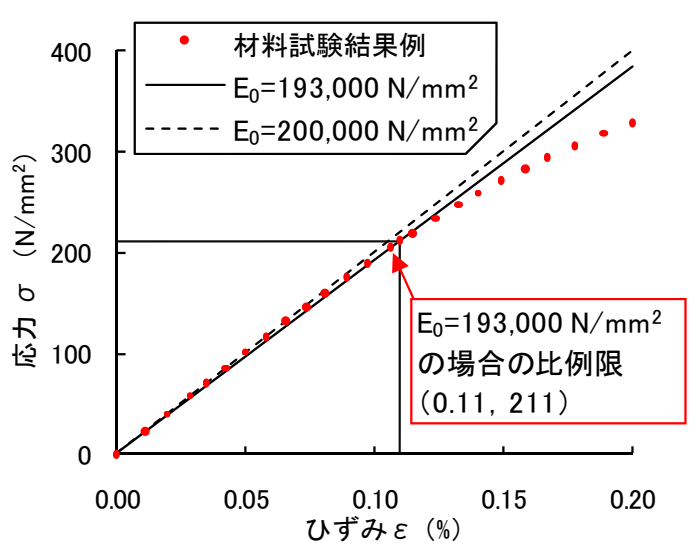

図-5 SUS304N2A の初期岡性と比例限 


$$
\left.\begin{array}{cc}
\left(\sigma / \sigma_{p}\right)=\left(\varepsilon / \varepsilon_{p}\right) & 0 \leq \varepsilon<\varepsilon_{p} \\
\left(\sigma / \sigma_{p}\right)=a_{1} \ln \left(\varepsilon / \varepsilon_{p}\right)+a_{p} \sqrt{\varepsilon / \varepsilon_{p}} & \\
+a_{3}\left(\varepsilon / \varepsilon_{p}\right)+a_{4} & \varepsilon_{p} \leq \varepsilon<b_{1} \varepsilon_{p} \\
\left(\sigma / \sigma_{p}\right)=a_{5}\left(\varepsilon / \varepsilon_{p}\right)+a_{6} & b_{1} \varepsilon_{p} \leq \varepsilon
\end{array}\right\}
$$

ここに， $\sigma_{p}$ および $\varepsilon_{p}$ は比例限度の応力度およびひずみ, $a_{1} \sim a_{6}, \quad b_{1}$ は材料試験結果から求まる定数である.

これらの構成式は原点から数\%程度のひずみに至るま で材料試験結果を精度よく表わせる利点を有する ${ }^{15,22,23)}$ 一方で，定式化のために多数の係数を材料試験結果から 求めなければならない，そこで，次式に示寸ような比例 限度と0.1\%耐力を折点としたトリリニア型の応力ーひず み関係趴提案されている.

$$
\left.\begin{array}{ll}
\sigma=E_{0} \varepsilon & 0 \leq \varepsilon<\varepsilon_{p} \\
\sigma=\left(1-\frac{0.001}{\varepsilon_{0.1}-\varepsilon_{p}}\right) E_{0} \varepsilon+\frac{0.001 E_{0} \varepsilon_{p}}{\varepsilon_{0.1}-\varepsilon_{p}} & \varepsilon_{p} \leq \varepsilon<\varepsilon_{0.1} \\
\sigma=E^{\prime} \varepsilon+\left(\varepsilon_{0.1}-0.001\right) E_{0}-E^{\prime} \varepsilon_{0.1} & \varepsilon_{0.1} \leq \varepsilon
\end{array}\right\}
$$

ここに， $E_{0}$ は初期弾性係数， $\varepsilon_{p}$ は比例限度でのひずみ, $\varepsilon_{0.1}$ は $0.1 \%$ 耐力でのひずみ, $E^{\prime}$ は $0.1 \%$ 耐力以降の弾性係 数である. これらの構成式から選択される本研究でのパ ラメトリック解析に用いる構成式については次節で詳述 する.

縦補岡材に用いるSM490Yは, 既往の研究結果を参考 に以下の構成式(24)用いる.

$$
\left.\begin{array}{lc}
\left(\sigma / \sigma_{y}\right)=\left(\varepsilon / \varepsilon_{y}\right) & \varepsilon \leq \varepsilon_{y} \\
\left(\sigma / \sigma_{y}\right)=1 & \varepsilon_{y} \leq \varepsilon \leq \varepsilon_{H} \\
\left(\sigma / \sigma_{y}\right)=B\left(\varepsilon / \varepsilon_{y}\right)^{\mathrm{n}} & \varepsilon_{H} \leq \varepsilon
\end{array}\right\}
$$

ここに, $B$ および $n$ はひずみ硬化領域における硬化パラ メータ， $\varepsilon_{H}$ はひずみ硬化開始ひずみを示す.

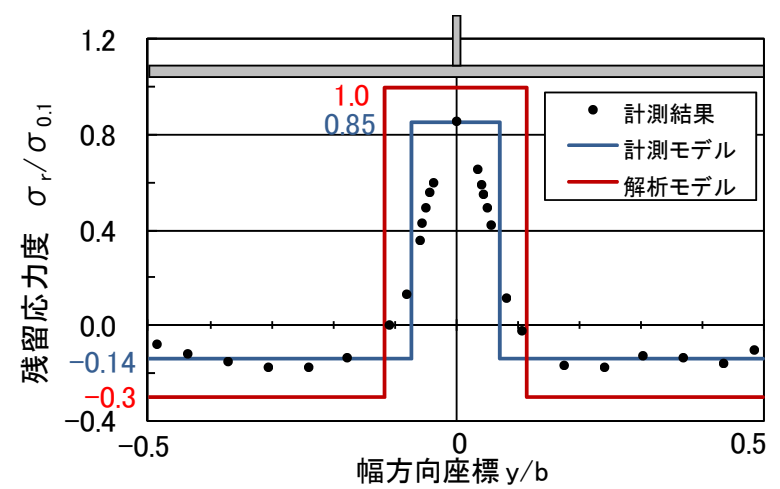

図-6 残留応力分布 (板パネル)

\section{（3）初期不整（残留応力および初期たわみ）}

残留応力および初期たわみに関する既往の研究8)は主 に構造用鋼が対象であり，ステンレス鋼に関しては，例 えば，藤井らによるステンレスクラッド鋼に着目した研 究25など限られている. そこで, 表-1に示す供試体の残 留応力および初期たわみの計測結果 1), 2)を用いてパラメ トリック解析に用いるモデルについて検討した.

\section{a) 残留応力}

表-1に示寸供試体種別 $\mathrm{A}$ の板パネルの残留応力計測結 果 ${ }^{1,2)}$ を図-6に示す。図中横軸は板幅方向の計測位置を供 試体全幅で除し，縦軸は計測された残留応力を $0.1 \%$ 耐力 で除して無次元化している. 構造用鋼に対する既往の研 究結果と同様1,2),8)，ハイブリッド補剛板においても溶接 部近傍に高い引張残留応力が発生し，その他の領域では ほぼ均等な圧縮残留応力が分布していることが分かる. そこで, 解析に用いる残留応力分布として, 計測から得 られた圧縮残留応力の平均值と引張残留応力の最大值を 用いて，釣り合い条件を考慮してモデル化した分布形状 を「計測モデル」として図中に併記した．計測された残 留応力分布形状は，構造用鋼のそれと同様であることか ら, 定性的傾向を評価していると言える. 他方で, 残留 応力度は構造用鋼より小さい值を示したものの，まだ定 量的に十分な評価とは言い難い. そこで，本研究では，

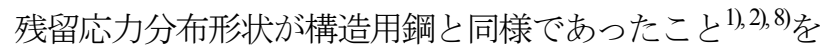
考慮し，構造用鋼での箱型断面鋼製橋脚の数值解析に用 いられる代表的な残留応力分布8)適用することとした. 具体的には図中の「解析モデル」で示すように実験モデ ルに比べ圧縮残留応力の平均值, および引張残留応力の 最大值を計測結果より高く設定したモデルを用いた。 ま た，縦補剛材に対する残留応力分布を図-7に示す. 図中 の縦軸は板幅方向の計測位置を板幅で除して無次元化し， 横軸は計測で得られた残留応力を使用鋼材(SM490Y)の 降伏点で除して無次元化している. 縦補剛材についても 板パネルと同様に構造用鋼に適用される代表的な応力分 布を参考としたが，モデルの簡便性を考慮して図中の 「解析モデル」で示寸矩形分布とした.

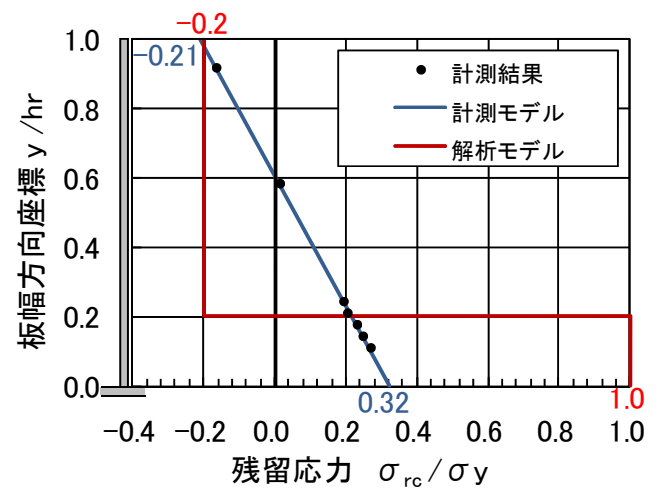

図-7 残留応力分布 (補剛材) 
設定した残留応力分布モデルの適用性を確認するため, 表-1の供試体種別Aを対象に表-2の解析CASE-1および CASE-2に対する弾塑性有限変位解析を行った。 なお, 表に示す通り，初期たわタおよび材料構成式のモデル化 は同じとした. これらのモデル化の詳細は後述の通りで ある.

図-8に解析から得られた荷重一軸方向平均ひずみ関係 を示す. 図中の縦軸は載荷荷重 $P$ を補剛板の全断面降 伏荷重 $P_{y}$ で除して無次元化している．以降，荷重およ びひずタは，これらの無次元量で評価するものとする. ここで，ハイブリッド補剛板は板パネルと縦補剛材で降 伏応力度が異なるため, 全断面降伏荷重 $P_{y}$ は次のよう に定義した。

$$
P_{y}=B_{0} \cdot t \cdot \sigma_{0.1}+h_{r} \cdot t_{r} \cdot \sigma_{y r}
$$

ここに， $\sigma_{0.1}$ は板パネル（SUS304N2A）の0.1\%耐力, $\sigma_{y r}$ は補剛材の降伏応力度で, $B_{0}, t, h_{r}, t_{r}$ はそれぞ れ表-1に示寸通りである. 図中横軸は軸方向縮みを供試 体長 $a_{0}$ で除した平均ひずみを $0.1 \%$ 耐力点での弾性成分 ひずみ $\varepsilon_{e}\left(=\sigma_{0.1} / E_{0}\right)$ で除して無次元化している.

図に示すように, 本研究で提案する残留応力分布を用 いたCASE-2では，計測結果に基づくCASE-1の解析結果 に比べ低い荷重から非線形性が生じるものの, 最大荷重 および最大荷重到達時の平均ひずみがCASE-1 と同程度 であることが分かる．また，その最大荷重はCASE-1お よびCASE-2ともに実験結果と同程度であることが分か
る. よって, パラメトリック解析に用いる残留応力分布 は図-6および図-7に示す「解析モデル」を用いる.

\section{b) 初期たわみ}

表-1の供試体種別Aの初期たわ久計測結果 ${ }^{1}$ を図-9(a) に示寸. 図に示寸ように初期たわみは複雑な形状を示し, 計測から得られた初期たわみ量の最大值は補剛板の曲が り（補剛板全体のたわみ）が $\delta_{0}=0.7 \mathrm{~mm}$, 板の平坦度 （縦補剛材間の局所的なたわみ）が $w_{0}=0.8 \mathrm{~mm}$ となり， それぞれ道路橋示方書の許容值 $\delta_{0 a}=1.0 \mathrm{~mm}(=$ $a / 1000), w_{0 a}=1.17 \mathrm{~mm}(=b / 150 n)$ よりも小さか った. 一方，パラメトリック解析では設計上安全側の耐 荷力評価の観点から, 局部座屈による変形モードを考慮 した上で，道路橋示方書の許容值を最大值となるように 初期たわみ分布を決定する必要がある ${ }^{89}$, 9)。そこで, 式(8)に示寸初期たわみ分布形状を用いることとした.

$$
\begin{aligned}
& w=\delta_{0} \sin (\pi x / a) \cos (\pi y / B)+ \\
& w_{0} \sin (\alpha \pi x / a) \sin (\pi y / b)
\end{aligned}
$$

ここに, $\delta_{0}=a / 1000, w_{0}=b / 150$ である. $\alpha$ は縦横の 補岡材に囲まれたサブパネルの縦横寸法比 $(=a / b)$,

$n$ は表-1に示すパネル数である. なお，式(8)に用いる 供試体の綐横寸法比は $\alpha=6(\fallingdotseq 1000 / 175)$ とした.

図-9(b)に式(8)を用いた初期たわみ形状を示す.

このような初期たわみモデルの差異がハイブリッド補 剛板の耐荷力特性に与える影響を把握するために，表-2 に示すCASE-3およびCASE-4の2ケースについて，表-1の 供試体種別Aを対象に弾塑性有限要素解析を行った。 な

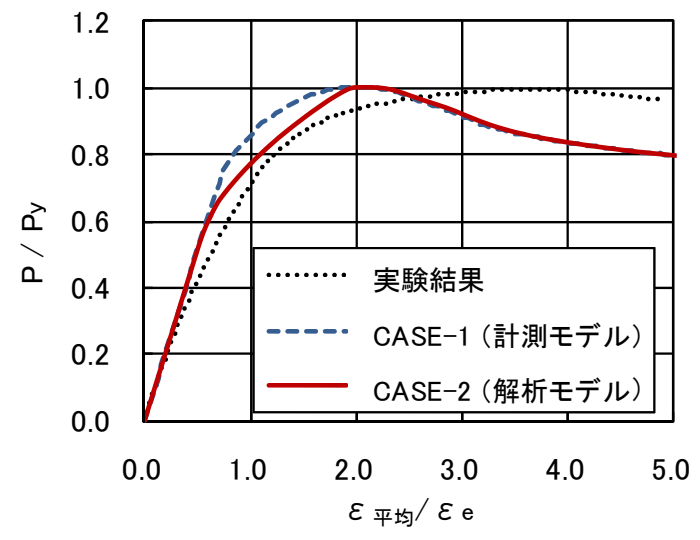

図-8 荷重-軸方向平均ひずみ

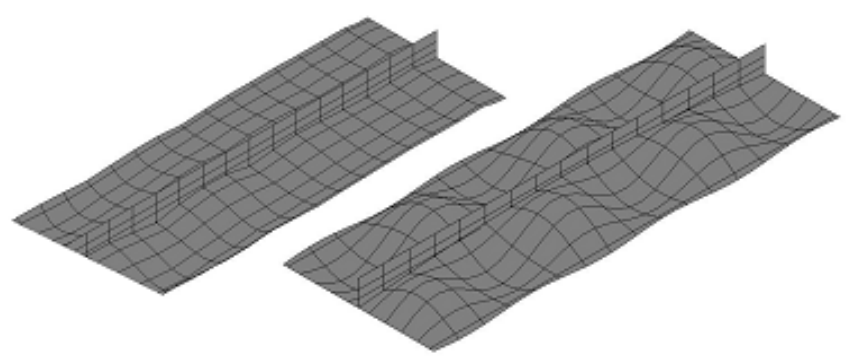

$\begin{array}{ll}\text { (a) 供試体計測結果 } & \text { (b) 式(8)による分布 }\end{array}$

\begin{tabular}{|c|c|c|c|c|c|c|}
\hline \multirow{2}{*}{$\begin{array}{l}\text { 解析 } \\
\text { CASE }\end{array}$} & \multirow{2}{*}{$\begin{array}{c}\text { 残留応力 } \\
\text { 分布 }\end{array}$} & \multicolumn{2}{|c|}{ 初期たわみ } & \multicolumn{2}{|c|}{ 材料構成式 } & \multirow{2}{*}{ 備考 } \\
\hline & & 分布形状 & 各係数 & 構成式 & 各定数 & \\
\hline 1 & 計測モデル & \multirow{2}{*}{\multicolumn{2}{|c|}{ 計測モデル(図-9(a)) }} & \multirow{4}{*}{ 式 (4) } & \multirow{4}{*}{ 表-5 } & 実験供試体の再現モデル \\
\hline 2 & 解析モデル & & & & & 残留応力分布の影響検討 \\
\hline 3 & \multirow{2}{*}{ 計測モデル } & \multirow{2}{*}{ 式(8) } & $\delta_{0}=0.7, W_{0}=0.8$ & & & \multirow{2}{*}{ 初期たわみ分布の影響検討 } \\
\hline 4 & & & $\delta_{0}=1.0, W_{0}=1.17$ & & & \\
\hline
\end{tabular}

図-9 初期たわみ形状（変形倍率 30 倍）

表-2 初期不整モデル化検討解析ケース（供試体種別 A ; 表-1） 
お，表-2に示寸ように残留応力分布および材料構成式は 同じとした．図-10に解析から得られた荷重一軸方向平 均ひずみ関係を示す．図中の縦軸および横軸は前述の図 -9に示寸通りである. 図に示すように, 供試体の初期た わみ計測結果を用いたCASE-1に対し，式(8)を用いた CASE-3およびCASE-4では剛性が低下を始める荷重に明 確な差は無いものの, 最大荷重および最大荷重に到達時 のひずみが低下した。 しかし，実験結果に対する最大荷

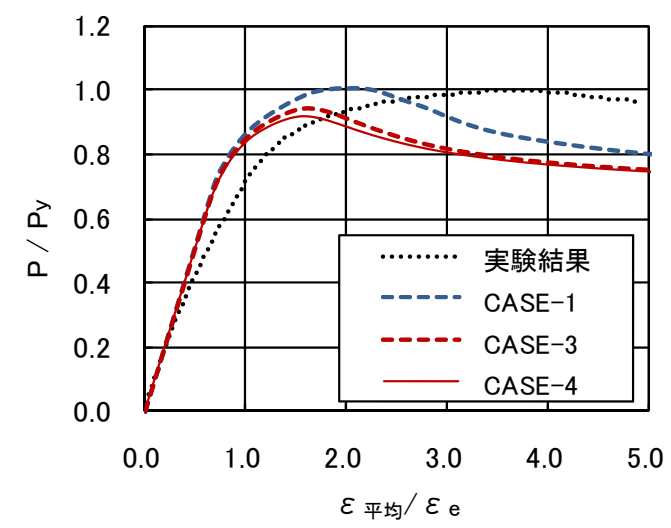

図-10 荷重-軸方向平均ひずみ（初期たわみの影響）

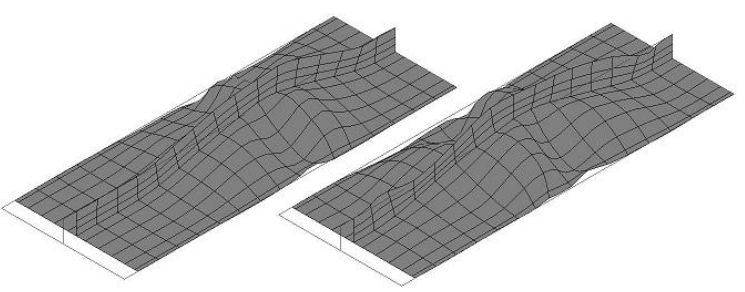

(a) CASE-1

(b) CASE-4

図-11 解析結果(座屈後の変形モード)

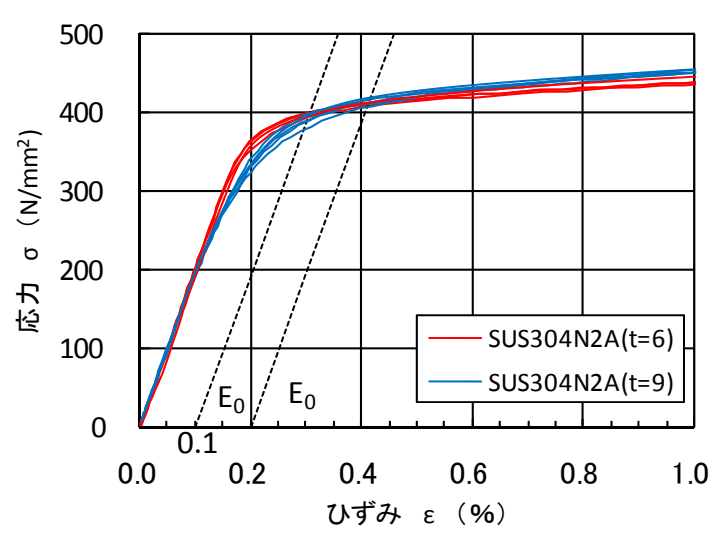

図-12 SUS304N2A材料試験結果の例
重の低下量はCASE-3で6\%程度，CASE-4で $8 \%$ 程度と少な い. また，図-11に示すようにCASE-4の座屈後の変形モ ードはCASE-1と同様であった。 以上より，パラメトリ ック解析に用いる初期たわみ分布は式(8)とし，その最 大值は道路橋示方書の規定值とする.

（4）公称値を用いたトリリニア型材料構成式の適用性 前述の通り，ステンレス鋼が有するラウンドハウス型 の応力ーひずみ関係に対し, Ramberg-Osgood曲線を始め その適用範囲や精度を向上させた種々の構成式が提案さ れている. しかし，本研究におけるJIS Z 2241に基づく SUS304N2Aの材料試験結果では，図-12に示すように板 厚などの違いにより厳密には応力ーひずみ関係にばらつ きが生じることが分かる，よって，これらの構成式を定 量化するためには, 多数の材料試験からその下限となる 基準曲線を与える係数群を設定する必要がある. その中 で，式(5)に示したトリリニア型の材料構成式は，簡便 で，公称值である0.1\%耐力の通過を保証し，かつ，比例 限度から降伏点における応力一ひずみ関係が常に材料試 験結果の下限值を与える. よって, 本研究では式(5)に 示すトリリニア型の材料構成式をパラメトリック解析に 用いることとした．式(5)の定式化にあたっては，公称 值である0.1\%耐力および初期弾性係数の他に, 比例限度 でのひずみ $\varepsilon_{p}$ と0.1\%耐力以降の弾性係数 $E^{\prime}$ 設定する 必要がある. そこで, 別途行ったSUS304N2A供試体の材 料試験結果から表-3に示寸通り決定した5)。 なお, 表中 には補剛材に用いるSM490Y材についても併記している. この様に決定した応力ーひずみ関係を図-13に示す.

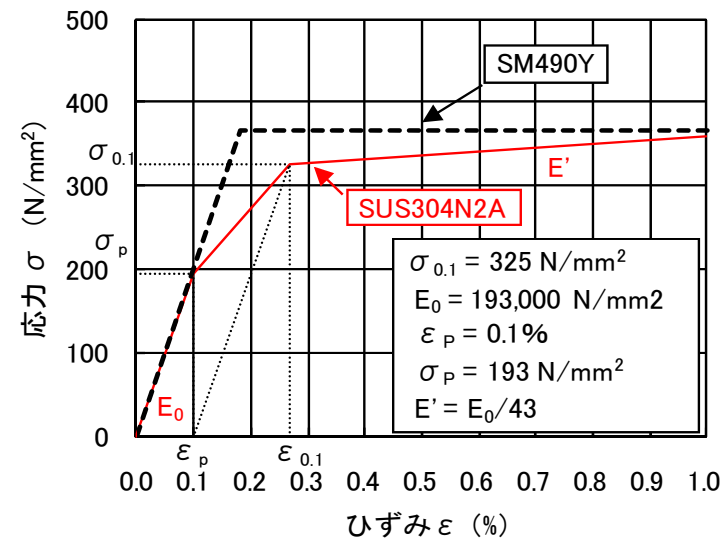

図-13 公称值を用いたトリリニア型構成式

表-3 トリリニア型構成式(5)で使用する公称值および各定数

\begin{tabular}{c|c|c|c|c||c|c}
\hline & \multicolumn{4}{|c||}{} & \multicolumn{2}{|c}{ 本研究での各定数 } \\
\hline \multirow{2}{*}{ 鋼 種 } & $\begin{array}{c}0.1 \% \text { 耐カ } \\
\sigma_{0.1}\left(\mathrm{~N} / \mathrm{mm}^{2}\right)\end{array}$ & $\begin{array}{c}\text { 引張強さ } \\
\sigma_{\mathrm{u}}\left(\mathrm{N} / \mathrm{mm}^{2}\right)\end{array}$ & $\begin{array}{c}\text { ポアソン 比 } \\
\nu\end{array}$ & $\begin{array}{c}\text { 初期弾性係数 } \\
\mathrm{E}_{0}\left(\mathrm{~N} / \mathrm{mm}^{2}\right)\end{array}$ & $\begin{array}{c}\text { 比例限度 } \\
\varepsilon \mathrm{p} \%)\end{array}$ & $\begin{array}{c}\text { 0.1\%耐カ以降の弾性係数 } \\
\mathrm{E}^{\prime}\left(\mathrm{N} / \mathrm{mm}^{2}\right)\end{array}$ \\
\hline SUS304N2A & 325 & 690 以上 & 0.3 & $1.93 \times 10^{5}$ & 0.1 & $\mathrm{E}_{0} / 43$ \\
\hline SM490Y & 355 (降伏点) & $490 \sim 610$ & 0.3 & $2.00 \times 10^{5}$ & \multicolumn{2}{|c|}{ 完全弾塑性モデル } \\
\hline
\end{tabular}


公称值を用いたトリリニア型の構成式の適用性を検討 するため，表-1の実験供試体を対象に弾塑性有限変位解 析を行い実験結果と比較した。解析では比較のため, 式(3)および式(4)の構成式を用いたケースも実施した. 式(3)および式(4)に用いる各定数は，材料試験結果から 表-4および表-5に示す通りとし，補剛材は式(6)を用いて $B=0.696, n=0.191, \varepsilon_{H}=6.66 \varepsilon_{y}$ とし ${ }^{24)}$, 降伏点は $\sigma_{y}=378 \mathrm{~N} / \mathrm{mm}^{2}$ とした1). 表-6に解析ケースをまとめる. 表-6に示すように，式(3)および式(4)の構成式を用いた場 合には初期たわみおよひ残留応力は供試体計測值とし, トリリニア型の式(5)を用いた場合にはそれぞれ本研究 で提案するモデルとした。
図-14および図-15に解析から得られた荷重一軸方向平 均ひず夕関係，表-7に最大荷重の比較結果を示す。なお， トリリニア型の構成式を用いた解析では降伏応力度に公 称值を用いており, 実験および式(3), 式(4)による解析 での降伏応力度と異なるため実荷重值あるいは実ひずみ 值を直接比較することが出来ない，そこで，最大荷重は 式(7)に示す全断面降伏荷重で無次元化し, 軸方向平均 ひずみは図-8と同様に降伏ひずみで除して無次元化した.

図-14に示すように供試体種別A（幅厚比パラメータ $R=0.7 ）$ では，トリリニア型の構成式である式(5)を用 いた場合，式(3)および式(4)での解析結果合に比べ早い 段階で岡性が低下し，最大荷重も低下するものの，表-7

表-4 Ramberg-Osgood の式(3)で使用する各定数

\begin{tabular}{c||c|c|c|c||c}
\hline $\begin{array}{c}\text { 板厚 } \\
(\mathrm{mm})\end{array}$ & $\begin{array}{c}\sigma_{0.01} \\
\left(\mathrm{~N} / \mathrm{mm}^{2}\right)\end{array}$ & $\begin{array}{c}\sigma_{0.2} \\
\left(\mathrm{~N} / \mathrm{mm}^{2}\right)\end{array}$ & $\begin{array}{c}\mathrm{E}_{0} \\
\left(\mathrm{~N} / \mathrm{mm}^{2}\right)\end{array}$ & $\begin{array}{c}\text { 硬化パラ } \\
\text { メタ } \\
\mathrm{n}\end{array}$ & 備考 \\
\hline 6 & 357 & 413 & 193000 & 20.7 & 種別A供試体解析用 \\
\hline ※硬化パラメータnは, $0.01 \%$ 耐カ点の通過条件 ${ }^{22)}$ から決定した.
\end{tabular}

表-5 中務・中村の式(4)で使用する各定数

\begin{tabular}{|c|c|c|c|c|c|c|c|c|c|c|c|}
\hline $\begin{array}{l}\text { 板厚 } \\
(\mathrm{mm})\end{array}$ & $\begin{array}{c}\sigma_{0.1} \\
\left(\mathrm{~N} / \mathrm{mm}^{2}\right)\end{array}$ & $\begin{array}{c}E_{0} \\
\left(\mathrm{~N} / \mathrm{mm}^{2}\right)\end{array}$ & $\begin{array}{c}\sigma_{\mathrm{p}} \\
\left(\mathrm{N} / \mathrm{mm}^{2}\right)\end{array}$ & $a_{1}$ & $a_{2}$ & $a_{3}$ & $a_{4}$ & $a_{5}$ & $a_{6}$ & $b_{1}$ & 備考 \\
\hline 6 & 406 & 193000 & $0.813 \sigma_{0.1}$ & 2.44 & -2.69 & -0.75 & 5.64 & 0.0166 & 1.22 & 3.07 & 供試体種別 A 解析用 \\
\hline 9 & 399 & 193000 & $0.503 \sigma_{0.1}$ & -0.23 & 2.04 & -0.83 & -2.25 & 0.0333 & 2.36 & 5.00 & 供試体種別 B 解析用 \\
\hline
\end{tabular}

※各定数は文献3)に示す材料試験結果を用いて再整理した.

表-6 解析ケースと初期たわみ，残留応力

\begin{tabular}{|c|c|c|c|c|c|c|}
\hline \multirow{2}{*}{ 解析対象 } & \multicolumn{2}{|c|}{ 材料構成式 } & \multicolumn{2}{|c|}{ 初期たわみ } & \multirow{2}{*}{ 残留応力 ${ }^{*)}$} & \multirow{2}{*}{ 備考 } \\
\hline & 構成式 & 各定数 & 分布形状 & 係数 & & \\
\hline \multirow{3}{*}{$\begin{array}{l}\text { 供試体 } \\
\text { 種別 A }\end{array}$} & 式(3) & 表-4 & \multirow{2}{*}{\multicolumn{2}{|c|}{ 計測結果 }} & \multirow{2}{*}{ 実験モデル } & Ramberg-Osgood 曲線 \\
\hline & 式(4) & 表-5 & & & & 中村らの式 \\
\hline & 式(5) & 表-3 & 式(8) & 道示許容値 & 解析モデル & トリリニア型構成式 \\
\hline \multirow{2}{*}{$\begin{array}{l}\text { 供試体 } \\
\text { 種別 B }\end{array}$} & 式 (4) & 表-5 & \multicolumn{2}{|c|}{ 計測結果 } & 実験モデル & 中村らの式 \\
\hline & 式(5) & 表-3 & 式(8) & 道示許容値 & 解析モデル & トリリニア型構成式 \\
\hline
\end{tabular}

※) 各モデルの詳細は, 図-6および図-7を参照のこと.

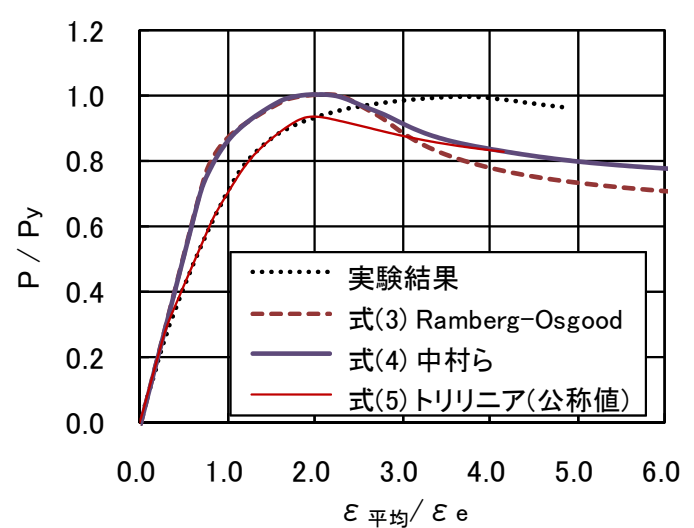

図-14 荷重一軸方向平均ひずみ（供試体種別 A ; 表-1）

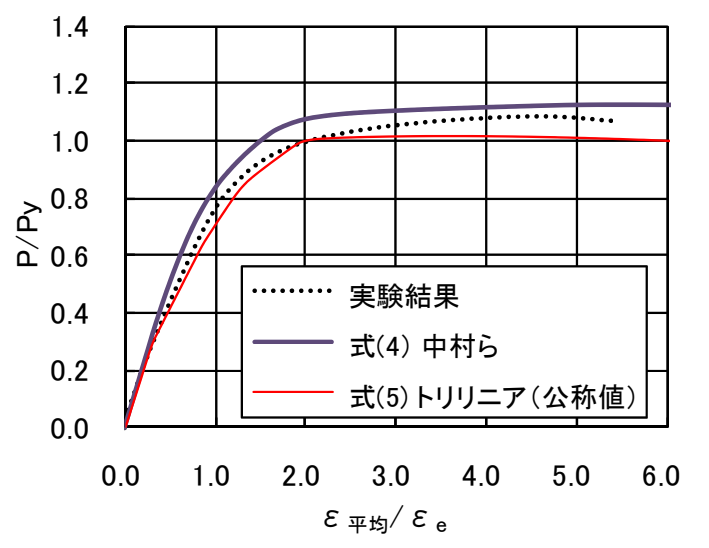

図-15荷重一軸方向平均ひずみ（供試体種別 B ; 表-1） 
表-7 無次元最大荷重の比較

\begin{tabular}{|c|c|c|c|c|}
\hline \multirow{3}{*}{$\begin{array}{c}\text { 供試体 } \\
\text { 種別 }\end{array}$} & \multirow{3}{*}{$\begin{array}{c}\text { 幅厚比パ } \\
\text { ラメータ } \\
\text { (R) }\end{array}$} & \multicolumn{3}{|c|}{ 最大荷重 (Pu/Py) } \\
\hline & & \multirow{2}{*}{$\begin{array}{l}\text { 実験 } \\
\text { 結果 }\end{array}$} & \multicolumn{2}{|c|}{ 解析結果 } \\
\hline & & & 式(4) & トリリニア式(5) \\
\hline A & 0.70 & 1.02 & $1.00(1.00)$ & 0.94 \\
\hline B & 0.47 & 1.08 & 1.12 & 1.02 \\
\hline
\end{tabular}

※( )内は式(3)による解析結果を示す.

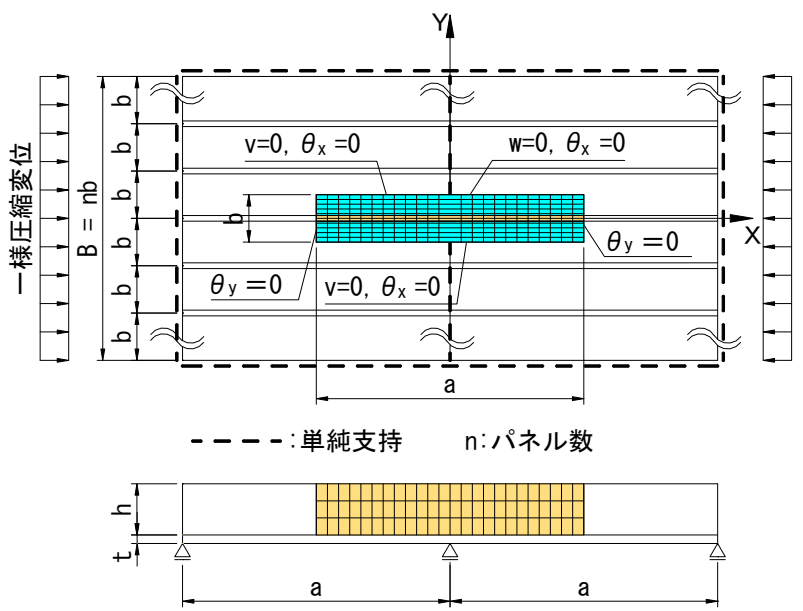

図-16＼cjkstart解析モデル (多リブモデル)
表-8 解析パラメータおよびその設定範囲

\begin{tabular}{|c|c|c|c|}
\hline \multicolumn{2}{|c|}{ 解析パラメータ } & 多リブモデル & 単リブモデル \\
\hline \multicolumn{2}{|c|}{ 鋼 種 } & \multicolumn{2}{|c|}{ SUS304N2A, SM400 } \\
\hline \multicolumn{2}{|c|}{ 幅厚比パラメータ $\mathrm{R}$} & \multicolumn{2}{|c|}{$0.4 \sim 1.2$ (0.1ごと） } \\
\hline 縦横寸法比 & $\alpha(=a / b)$ & $2,4,6,8$ & $2,4,6$ \\
\hline 補剛材剛比 & $\gamma / \gamma_{\text {req }}$ & & 3 \\
\hline \multirow{3}{*}{ 要素分割 } & 長さ方向 & $6 \times$ & 分割 \\
\hline & 幅方向 & 10 分割 & 12 分割 \\
\hline & 補剛材高さ方向 & \multicolumn{2}{|c|}{3 分割 } \\
\hline
\end{tabular}

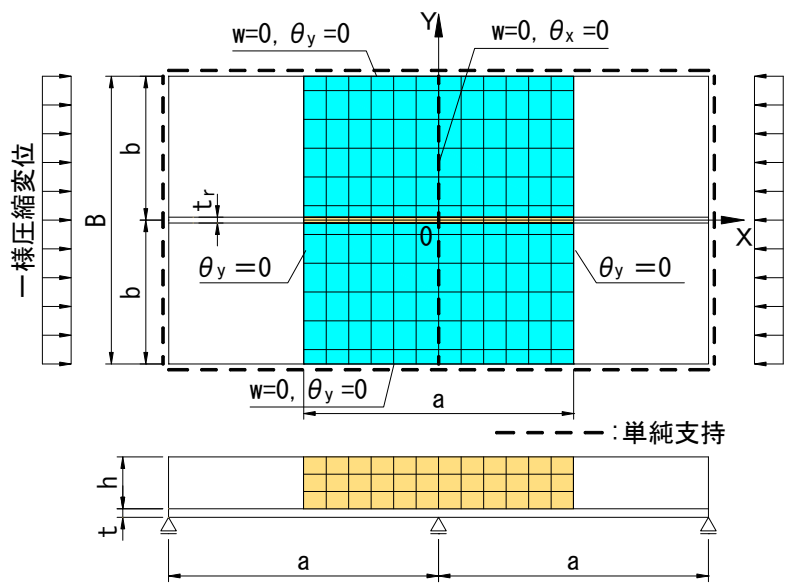

図-17＼cjkstart解析モデル（単リブモデル）

ると仮定して横補剛材位置で単純支持としている，要素 分割は表-8に示す通りとし，既往の研究結果 ${ }^{20}$ を参考に 事前の解析により必要な精度が得られる分割数であるこ とを確認している，また，荷重は載荷辺上に一様な相対 強制変位を与えることにより一様軸圧縮応力を導入した. 解析に用いる構成式は式(5)および表-3に示すトリリニ ア型とし，残留応力分布は図-6および図-7に示寸解析モ デル，初期たわみ分布は式(8)に示寸通りとした.

\section{(2) 解析パラメータ}

解析パラメータとして，縦横寸法比，幅厚比パラメー 夕，および縦補剛材剛比に着目し，その設定範囲を表-8 に示す通りとした．すなわち，多リブモデルおよび単リ ブモデルに対して，それぞれ，9×4×2=72ケースおよび $9 \times 3 \times 2=54$ ケースの終局強度解析を行った. 各パラメー 夕の範囲は既往の研究8) 参考に, 橋梁での適用範囲を 想定して決定した。 また，解析ではハイブリッド補剛板 の他，比較のためにSM400を用いた構造用鋼補剛板も対 象とした．なお，表中の縦横寸法比は，補剛材で囲まれ たサブパネルの縦横寸法比 $\alpha=a / b$ を示し, 以下の解 析結果も同様とする. 


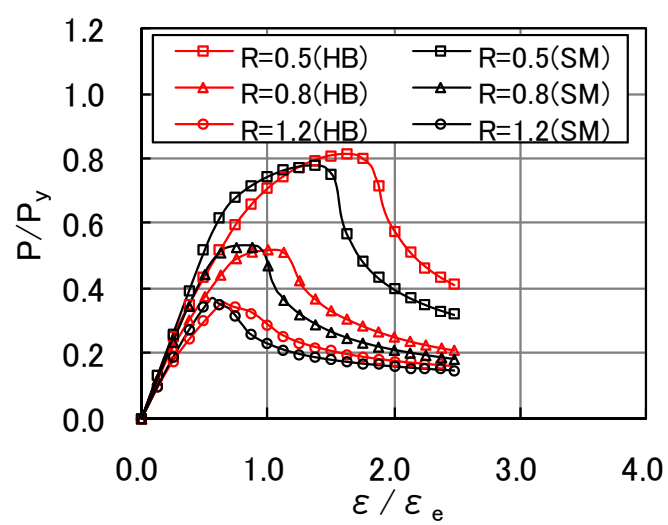

(a) 多リブモデル

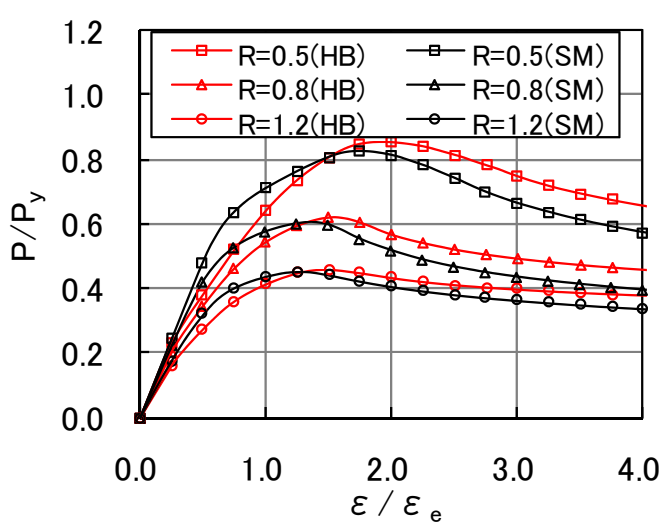

(b) 単リブモデル

図-18 荷重一軸方向平均ひずみ関係 $\left(\alpha=2, \gamma / \gamma_{r e q}=1\right)$

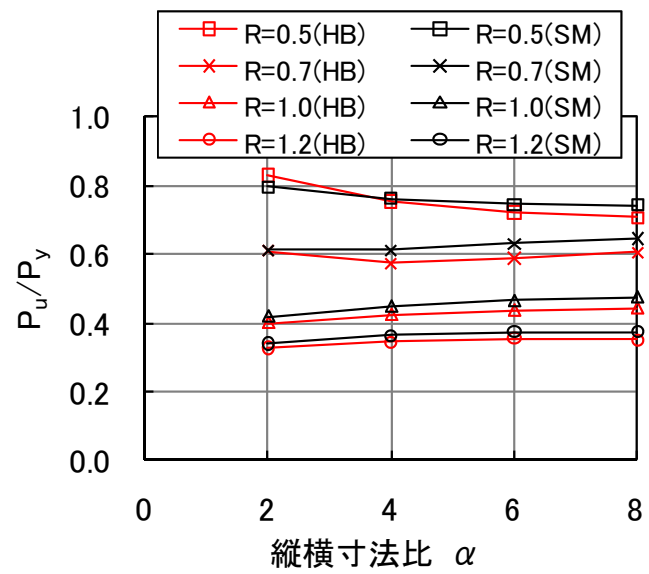

図-19 縦横寸法比と最大荷重 (多リブモデル, $\gamma / \gamma_{\text {req }}=1$ )

\section{(3) 解析結果}

\section{a) 荷重一軸方向平均ひずみ関係}

縦横寸法比 $\alpha=2$, 縦補剛材剛比 $\gamma / \gamma_{r e q}=1$ での代 表的な幅厚比パラメータにおける荷重一軸方向平均ひず み関係を図-18に示す。図中縦軸および横軸は図-8と同 様に無次元化している. また, 眓中の凡例に示すように, 以下ではハイブリッド補剛板を $\mathrm{HB}$ ，構造用鋼補剛板を SMで示す。困に示すように, 補剛板の種類（HB， SM）によらず，幅厚比パラメータの増加に伴い最大荷 重が低下すること，および，多リブモデルでは特に幅厚 比パラメータが小さい場合に最大荷重到達後の荷重の低 下が顕著であることが分かる. 一方, 同じ幅厚比パラメ 一タにおいてHB補剛板はSM補剛板に比べ，初期の段階 から岡性が低下し最大荷重到達時の軸方向平均ひずみが 増加するものの, 最大荷重の差異は小さいことが分かる. これは，図-13に示すように構造用鋼に比べステンレス 鋼の比例限度が低いために，初期の段階から軸方向平均 ひずみが増加したものの, 比例限度到達後の岡性により, ひずみが急増せず，結果として最大荷重の差異が小さか ったものと考えられる.

\section{b) 縦横寸法比の影響}

図-19に解析から得られた多リブモデルの最大荷重に ついて縦横寸法比に着目した結果を示す。補剛材剛比は $\gamma / \gamma_{\text {req }}=1$ である. 困に示す様に, $\alpha$ の増加に伴い最大 荷重は増加する傾向にあるが， $R=0.5$ の場合には $\alpha$ の 増加に伴い最大荷重が低下した. 図-20は, $\alpha=8$ の場合 の最大荷重到達時の変形モード図である. 図に示す様に, $R=0.5$ の場合には補剛板全体の座屈が卓越しているこ とか分かる. なお, $\alpha$ の増加に伴い最大荷重の変化量は 減少し, $\alpha=6$ に対する $\alpha=8$ の変化量は最大でも $3 \%$ 程 度であった。また，以上の結果はHB補剛板とSM補剛板 で差異は見られなかった。

図-21に代表的な縦横寸法比 $\alpha$ における最大荷重と幅 厚比パラメータの関係について, HB補剛板とSM補剛板 を比較した結果を示す. 補剛材剛比は $\gamma / \gamma_{r e q}=1$ である. なお，図中には弾性座屈曲線も併記している．困に示す ようにHB補岡板の最大荷重は, 多リブモデルで $\alpha=8$ の場合にSM補剛板に比べ若干の低下がみられるものの, その他のケースではSM補剛板と同程度となることが分 かる. 


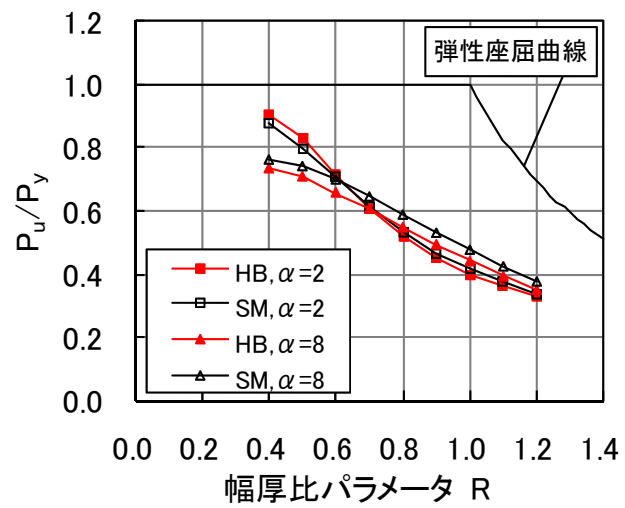

(a) 多リブモデル

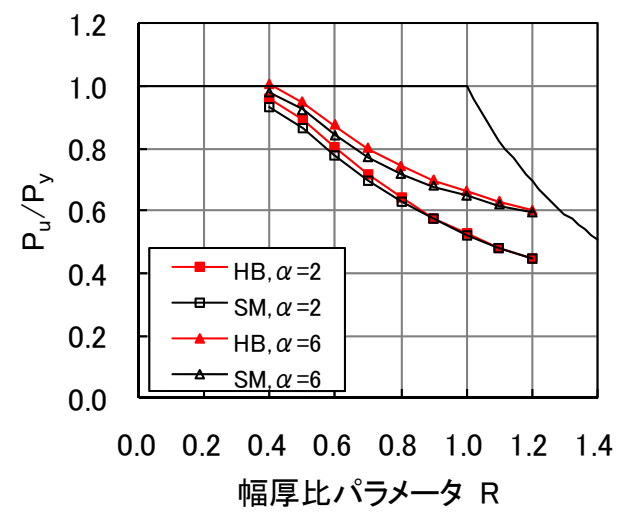

(b) 単リブモデル

図-21 最大荷重一幅厚比パラメータ相関に及ぼす縦横寸法比の影響

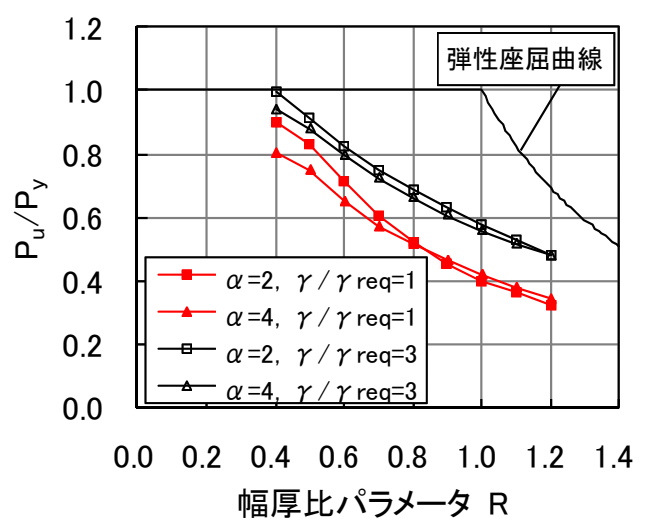

(a) 多リブモデル

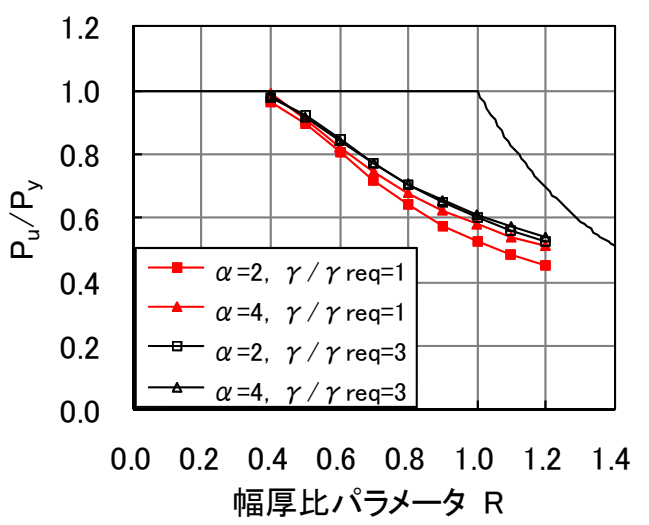

(b) 単リブモデル

図-22 最大荷重一幅厚比パラメータ相関に及ぼす補岡材剛比の影響

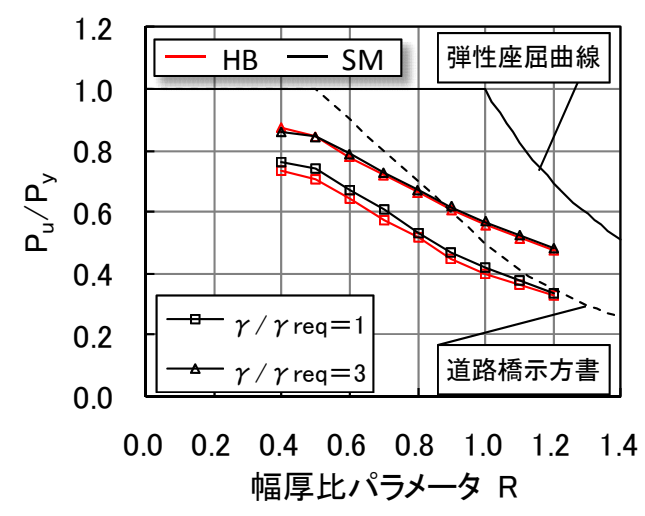

(a) 多リブモデル

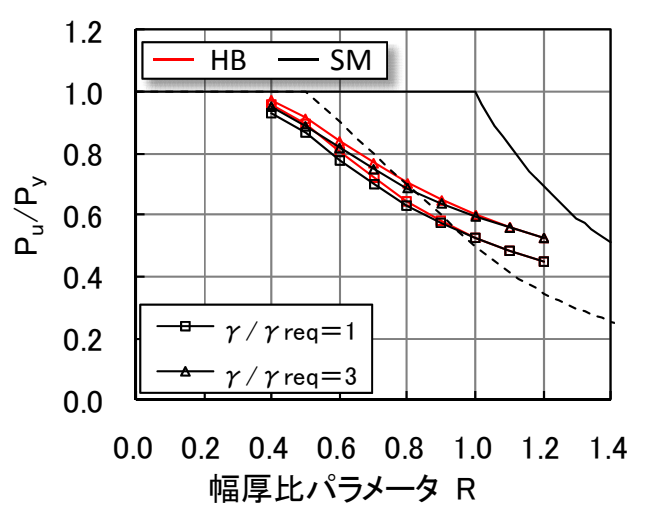

(b) 単リブモデル

図-23 而荷力曲線

\section{C) 補剛材剛比の影響}

$\mathrm{HB}$ 補剛板に対する最大荷重と幅厚比パラメータの関 係について，補剛材剛比の影響に着目した結果を図-22 に示す. 図に示すように多リブモデルでは $\alpha$ に関わらず 補剛材剛比の増加により最大荷重が $10 \%$ 以上増加するこ とが分かる. 一方, 単リブモデルでは $\alpha=2$ の場合で, かつ, 幅厚比パラメータが比較的大きい場合に最大荷重 が増加することが分かる。

\section{d) 耐荷力曲線}

本研究で解析したすべての無次元最大荷重 $\left(P_{u} / P_{y}\right)$ から, 幅厚比パラメータ毎の最小值を抽出したものが, 図-23に示す耐荷力曲線である。図中には，道路橋示方

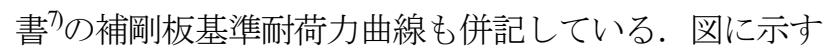
ように, 多リブモデルでは, 幅厚比パラメータが小さい 領域でHB補剛板の耐荷力がSM補剛板よりも若干低下す る一方, 単リブモデルでは幅厚比パラメータによらず概 
初同程度以上の耐荷力を有していることが分かる。なお， $\mathrm{SM}$ 補剛板に対するHB補剛板の無次元最大荷重の比率は, 多リブモデルでの全解析ケース（全72ケース）において, 最大 $104.2 \%$ ，最小 $92.8 \%$ ，平均 $97.2 \%$ であり，単リブモデ ル（全54ケース）では最大 $103.9 \%$ ，最小 $99.0 \%$ ，平均 101.8\%であった.

以上より, 本研究でのパラメータの範囲内において, SUS304N2Aを用いたハイブリッド補剛板の而荷力は, $0.1 \%$ 耐力を使用し，式(7)に示寸全断面降伏荷重で無次元 化することにより，従来の構造用鋼補剛板と同等の評価 が可能であると考えられる.

\section{4. まとめ}

本研究では，ステンレス橋梁に用いられるハイブリッ ド補剛板の軸圧縮而渮力特性を明らかにするために，パ ラメトリックな解析的検討を行った．まず初めに，別途 実施した耐荷力実験結果を用いてパラメトリック解析に 用いる初期不整（初期たわみおよび残留応力）のモデル 化，および著者らが提案するトリリニア型の材料構成式 の適用性について弾塑性有限変位理論による解析結果と の比較により検討した．次に，検討結果を踏まえて解析 モデルを決定し，ハイブリッド補剛板の最大荷重に影響 を及ぼすと考えられる因子を変化させてパラメトリック 解析を行い，その軸圧縮而荷力特性を明らかにした。

本研究で得られた主な結論をまとめると以下の通りと なる.

(1) 本研究で提案したトリリニア型の構成式, および 初期不整を用いた実験供試体の解析結果は, ラウンドハ ウス型の構成式を用いて実験供試体の初期不整を再現し た解析結果に比べ，剛性低下が始まる荷重，および最大 荷重が低くなる。しかし，最大荷重の差異は6〜10\%程 度であり実験結果と比較した場合でも6 8\%程度と小さ い. よって，ハイブリッド補剛板の軸耐荷力特性を把握 するための解析手法として適用可能であると考えられる。

(2) 荷重一軸方向平均ひずみ関係において，ハイブリ ッド補剛板は構造用鋼補剛板に比べ低い荷重で岡性が低 下し，最大荷重到達時の軸方向平均ひずみが大きい，こ れは，ステンレス鋼が構造用鋼と比べ比例限度が低く， 初期の段階からが弾性係数が低下寸るためと考えられる. (3) 幅厚比パラメータRが一定の場合, 縦横寸法比 $\alpha$ の増加に伴い最大荷重はわずかではあるが増加する傾向 にあった。

（4）縦補剛材剛比を増加させることにより，多リブモ デルでは縦横寸法比，幅厚比パラメータによらず最大荷 重が10\%以上増加した. 一方, 単リブモデルでは $\alpha$ 小 さく, かつ, 幅厚比パラメータが比較的大きい場合にの
み最大荷重が増加した.

(5) 本研究で用いたパラメータの範囲において, 多リ ブモデルでは幅厚比パラメータが小さい領域でハイブリ ッド補剛板の無次元耐荷力が構造用鋼補岡板のそれより も若干低下寸る傾向にあり, 単リブモデルでは幅厚比パ ラメータによらず概ね同程度以上の耐荷力を有していた。

(6) 構造用鋼補剛板に対するハイブリッド補剛板の無 次元最大荷重の比率は, 多リブモデル（全72ケース）で は最大 $104.2 \%$, 最小 $92.8 \%$, 平均 $97.2 \%$ であり, 単リブモ デル（全54ケース）では最大 $103.9 \%$ ，最小 $99.0 \%$ ，平均 101.8\%であった.

以上より, 本研究でのパラメータの範囲内において, SUS304N2Aを用いたハイブリッド補剛板の耐荷力は, $0.1 \%$ 而力使用し, 式(7)に示寸全断面降伏荷重で無次元 化することにより，従来の構造用鋼補岡板と同等の評価 が可能であると考えられる.

本研究では, ステンレス橋梁の実用化に向けて, 従来 の構造用鋼からなる補剛板との比較を中心にハイブリッ ド補剛板の軸圧縮而何力特性を検討した. よって, その 構造詳細の一部である補剛材剛比の設定では道路橋示方 書の規定を参考にし, また, 残留応力分布については, 限られた実験結果を補完する形で既往の構造用鋼の残留 応力に関する知見を参考とした．また，実験との比較は 単リブモデルのみで，それを多リブモデルに展開してい る点など, 結論の汎用性の点ではいくつかの課題が残さ れている.

今後，著者らが提案するステンレス橋梁の実用化を促 進するためには, 残留応力分布などの基礎資料を充実さ せるとともに，さらに数多くの実験やパラメトリック解 析を行い，ステンレス橋梁に適した設計手法を確立する 必要がある。また，ハイブリッド構造を採用した場合の 部材結合部の防食対策を含む各部の構造詳細や，その製 作方法の確立など，設計のみならず製作，施工上の課題 に対する研究も進める必要がある.

\section{参考文献}

1) 松下裕明, 岩田節雄, 有住康則, 矢吹哲哉: ステン レス鋼板を普通鋼で補剛したハイブリッド補剛板の 軸圧縮耐荷力特性, 構造工学論文集, Vol.49A, pp.833-844, 2003.

2) 中谷光良, 谷和彦, 大澤守彦, 松下裕明, 矢吹哲哉, 有住康則：ステンレス鋼溶接における溶接変形推定 方法及び残留応力の検討, 溶接構造シンポジウム 2002 講演論文集, 2002.11

3) 楠和憲, 松下裕明, 友野裕, 矢吹哲哉他: ステンレ 又橋梁用候補材の耐候性評価暴露試験（第 2 報）, 第 58 回土木学会年次学術講演会講演概要集, 2003.

4) 松下裕明, 矢吹哲哉, 有住康則, 岩田節雄 : ステン レス鋼を用いた I 形断面桁腹板のせん断耐荷力に関す る実験的研究, 構造工学論文集, Vol.50A, pp.799- 
$808,2004$.

5) 松下裕明, 矢吹哲哉, 有住康則, 岩田節雄 : せん断 を受けるステンレス鋼板の耐荷力特性，構造工学論 文集，Vol.52A，pp.865-874，2006.

6) 有住康則, 矢吹哲哉, 下里哲弘, 池宮真人, 松下裕 明：ステンレス鋼を用いた圧縮フランジの耐荷力評 価, 構造工学論文集, Vol.55A, pp.68-79, 2009.

7) 日本道路協会 : 道路橋示方書 ・同解説 I 共通編 $・$ II 鋼 橋編, 2012.3

8) 土木学会 : 座屈設計ガイドライン改訂第二版, 丸善, 2005.10

9) 北田俊行, 中井博, 越智内士 : 高張力鋼を用いた圧 縮板・圧縮補剛板の終局強度に関する研究, 構造工 学論文集, Vol.46A, pp.179-190, 2000.

10) 松下吉男, 加藤勉 : ステンレス橋 SUS304N2 を用い た $\mathrm{H}$ 形断面部材の局部座屈耐力と変形能力, 構造工 学論文集, Vol.39B, pp.575-582, 1993.

11）松下吉男，加藤勉：局部座屈を伴う閉断面ステンレ 又鋼部材の最大耐力と変形能力, 構造工学論文集, Vol.40B, pp.637-644, 1994.

12) ステンレス建築構造設計基準作成委員会：ステンレ ス建築構造設計基準・同解説（第二版），ステンレ 又構造建築協会, 2001.

13）三好崇夫，宮岦靖大，奈良敬：二相系ステンレス鋼 板の極限圧縮強度特性, 構造工学論文集, Vol.55A, pp.80-91， 2009.

14) 宮齐靖大, 奈良敬：無補剛ステンレス鋼圧縮板の座 屈照査法, 構造工学論文集, Vol.56A, pp.122-134, 2010.

15) 森章吾, 三好崇夫, 越智内士, 宮峷靖大, 奈良敬 : ステンレス鋼の応力ーひずみモデルが終局強度に及 ぼす影響について, 鋼構造年次論文報告集，第 15 巻, pp.645-652, 2007.

16) 日本規格協会：JIS Z 2241 金属材料試験方法, 1998.12

17) 日本規格協会 : JIS G 0202 鉄鋼用語（試験） No.1164
耐力, 2008.10

18）日本規格協会 : JIS G4321 建築構造用ステンレス鋼材 解説, 2010.10

19) Baddoo, N. R. : A comparison of structural stainless steel design standards, Stainless Steel in Structures (Proc. The Second Experts Seminar), The Steel Construction Institute, pp.131-150, 2003.

20) Ramberg, W. and Osgood, W. R. : Description of stressstrain curves by three parameters, Technical Note No.902, National Advisory Committee for Aeronautics, 1943.

21) Specification for the Design of Cold-Formed Stainless Steel Structural Members (8-02), Standards ASCE/SEI 802, American Society of Civil Engineers, 2002.

22) Nethercot, D. A. and Gardner, L. : Exploiting the special features of stainless steel in structural design, Journal of Applied Mechanics and Engineering, Vol. 9, No. 1, pp. 723, 2004.

23) 中務尚美, 中村武 : 金属系新素材 - 新材料の利用技 術の開発（建設省プロジェクト・新素材）その 27 SUS304 ステンレス H 形断面材の座屈耐力に関する実 験的研究, 日本建築学会学術講演気梗概集, 1991.9

24）奈良敬, 近藤真司：ハイブリッド圧縮補剛板の極限 強度と変形性能, 鋼構造年次論文報告集, 第 6 巻, 1998.11

25) 藤井堅. 三木千寿, 藤井崇文 : ステンレスクラッド 鋼板の軸圧縮耐荷力と残留応力, 土木学会論文集, 第 633 号/I-49, pp.181-192, 1999.

26）奈良敬, 小松定夫, 北田俊行 : 連続補剛板の極限圧 縮強度特性に関する研究，土木学会論文集，第 392 号/I-9, pp.273-280, 1988.4

27) 奈良敬, 小松定夫 : 補剛された圧縮版の極限強度曲 線に関する統計学的研究，土木学会論文集，第 392 号/I-9, pp.289-296, 1988.4

\title{
ULTIMATE COMPRESSIVE STRENGTH OF HYBRID STAINLESS STEEL PLATES STIFFENED WITH MILD CARBON STEEL RIBS
}

\author{
Hiroaki MATSUSHITA, Tetsuya YABUKI, Yasunori ARIZUMI \\ and Tetsuhiro SHIMOZATO
}

In order to decrease the life cost of steel bridges, we propose to use hybrid stiffened plates of stainless steel plates stiffened with mild carbon steel ribs. The mechanical properties of stainless steels, however, differ from those of mild structural steel. The effect of those different properties on the ultimate strength of the hybrid plates should be clarified. This paper described analytical result on the ultimate compressive strength of the hybrid plates and found that the hybrid plates show almost same strength of ordinary stiffened steel plates. The analytical model used in the parametric analysis was validated with experimental results. 